\title{
Entrevista com Marieta de Moraes Ferreira
}

\author{
Patricia Aranha ${ }^{1 *}$ \\ Claudio Correa ${ }^{2 * *}$ \\ ${ }^{1}$ Faculdade de Filosofia, Letras e Ciências Humanas da Universidade de São Paulo, São Paulo, Brasil \\ ${ }^{2}$ Universidade do Estado do Rio de Janeiro, Rio de Janeiro, RJ, Brasil \\ Entrevista concedida em 30 de agosto de 2017 no Rio de Janeiro \\ Revisada em 30 de julho de 2018
}

Marieta de Moraes Ferreira é diretora executiva da Editora da Fundação Getulio Vargas e professora titular aposentada da Universidade Federal do Rio de Janeiro. Atua como pesquisadora e professora junto ao Programa de Pós-graduação em História Social da UFRJ. Foi idealizadora e primeira presidente da Associação Brasileira de História oral, tendo também presidido a Internacional Oral History Association. Dirigiu o Centro de Pesquisa e Documentação de História Contemporânea do Brasil e, mais recentemente, fez parte do grupo que elaborou o Mestrado Profissional em Ensino de História, que coordenou até o fim de 2017. Sua trajetória é marcada principalmente por estudos relacionados à História do Brasil Republicano, pesquisando em campos como a História do Rio de Janeiro, a História oral, História do Tempo Presente, Estudos sobre Memória e História Política. São de sua autoria os livros $A$ História como Ofício - A constituição de um campo disciplinar (Ed. FGV, 2013), Rio de Janeiro: uma cidade na história (Ed. FGV, 2000), Usos e abusos da História oral (Ed. FGV, 1996), dentre outros.

Entrevistadores: Nossa primeira pergunta é: por que História? Como foi a decisão pelo curso universitário?

Marieta Moraes Ferreira: Na verdade, na minha adolescência, e mesmo durante o Ensino Médio, nunca cogitei estudar História. Até porque eu tinha muito pouco contato com o ensino de História, com livros didáticos bons. Embora tenha nascido no Rio de Janeiro, me criei em Nova Friburgo e estudei num colégio de freiras, no Colégio Nossa Senhora das Dores. Lá havia disciplinas que eram melhores, com uma estrutura de ensino mais interessante... mas os cursos de História, ao longo do Ensino Fundamental, que na época se chamava ginásio, e depois, na escola normal, eram realmente muito ruins. Não havia um investimento pra estudar História, para conhecer a História. Me lembro que usávamos o livro do Borges Hermida ${ }^{1}$ e que era necessário

DOI: http://dx.doi.org/10.1590/2237-101X02004002

* Pós-doutoranda da Faculdade de Filosofia, Letras e Ciências Humanas da Universidade de São Paulo e Bolsista da Fundação de Amparo à Pesquisa do Estado de São Paulo (FAPESP) processo número 2017/20819-5. E-mail: p.aranha2909@gmail.com. https://orcid.org/0000-0003-3344-2051

${ }^{* *}$ Mestrando pelo Programa de Pós-graduaçáo em História da Universidade do Estado do Rio de Janeiro e Bolsista do Conselho Nacional de Desenvolvimento Científico e Tecnológico (CNPq). E-mail: correa.arqui- 
decorar as capitanias hereditárias.

Havia outras disciplinas que eram boas. Por exemplo, o Francês. Minha professora era uma freira, sabia muito bem; tive bons professores de Língua Portuguesa. Algumas disciplinas tinham uma abordagem interessante, mas a História não. Eu nunca tive bons professores e também não tinha bons livros didáticos, os livros didáticos naquela época não eram interessantes. E isso não era uma especificidade daquele colégio, era uma regra geral. Me formei e vim para o Rio de Janeiro, náo queria continuar morando em Nova Friburgo. Quando eu cheguei, não sabia muito bem o que queria fazer, sabia que faria algum curso na área de humanas, mas minha primeira opção era Psicologia.

Em seguida, comecei a fazer um curso pré-vestibular no Centro da Cidade, que se chamava Curso Platáo, na área de ciências humanas, com o objetivo de fazer o vestibular para o curso de Psicologia. Neste curso, eu fui aluna de um professor que me marcou profundamente, que se chama Ilmar Rohloff de Mattos. Acho que todos os seus alunos foram muito influenciados por ele. Ele era meu professor de História do Brasil e então passei a ver História de outra maneira e comecei a ter muito interesse pela disciplina. E, na verdade, estudei lá apenas quatro meses. Entrei em março e fui até junho, porque, no meio de 1969, abriu um vestibular de meio de ano na Universidade Federal Fluminense.

Parece que as vagas para o primeiro período não haviam sido preenchidas e eles abriram uma segunda seleção. Naquela época não havia vestibular unificado, cada Universidade fazia o seu vestibular. Então, as pessoas comentaram no Curso Platão sobre este vestibular e eu resolvi prestar para ver como era, até porque eu me achava com muito menos competência que a maioria dos meus colegas. Uma boa parte deles tinha vindo do Colégio de Aplicação, do André Maurois, colégios considerados de ponta. Eles já conheciam Caio Prado Júnior, Nelson Werneck Sodré, autores que eu não tinha a menor ideia de quem eram. Resolvi fazer para sentir como era a prova. Então, estudei muito em casa. No curso pré-vestibular, só tínhamos visto uma parte do programa, a do primeiro semestre. Fiz a prova no meio de julho e passei, até tirei a maior nota em História.

Depois pensei: "Será que me inscrevo ou não?" Porque, nessa altura dos acontecimentos, o curso da Universidade Federal do Rio de Janeiro era bastante problemático. A UFRJ tinha sofrido um processo muito intenso de repressão, com a cassação dos professores. A alternativa era ir para a Universidade Federal Fluminense, que estava despontando naquele momento, visto que não enfrentava os mesmos problemas. Como ela ainda não tinha grande projeção, também não tinha sido objeto de forte repressáo.

A mudança no curso da UFF aconteceu exatamente neste ano em que eu entrei, que foi o ano das cassaçóes na UFRJ. Em 1968, Maria Yedda Linhares, Eulália Lobo, os assistentes da Maria Yedda Linhares, o próprio Francisco Falcon se afastaram; houve um esvaziamento 
muito grande dos principais professores. Jose Luis Werneck também ficou afastado, Manuel Maurício, enfim... E, por outro lado, havia a situação da repressão dentro da sala de aula. Me lembro que até cogitei fazer prova para a UFRJ. Mas as pessoas falavam: "não faz prova para a UFRJ, porque lá a polícia fica dentro da sala vigiando o que os professores estão ensinando." E isso assustava todo mundo. Eu realmente optei por fazer UFF. Até pensei na possibilidade de fazer na Pontifícia Universidade Católica, mas, de qualquer forma, a UFRJ não fazia parte das minhas opçôes, depois dessas informaçóes que eu tinha recebido. Comecei a fazer o curso na UFF, para ver como era o primeiro período, e aí acabei ficando. $\mathrm{O}$ curso começou a crescer, tinha professores interessantes como o Francisco Falcon, de História Moderna e Contemporânea, Almir Chaiban... E era muito engraçado, porque em plena Ditadura Militar a gente tinha um curso todo baseado na teoria Marxista.

Entrevistadores: Como a senhora sabe, recentemente temos pensado muito na História das Mulheres, nas trajetórias femininas na Universidade, de historiadoras e geógrafas. Como foi para a senhora essa entrada na Universidade como mulher no fim dos anos 1960 e início dos anos 1970? E, também, como foi essa orientação com a Professora Ismênia Martins, que era uma jovem mulher?

Marieta de Moraes Ferreira: Na verdade, nesse período de 1969, 70, 71, eu não tinha essa consciência do feminismo. A minha família vinha do mundo rural, proprietários rurais, e as mulheres eram muito oprimidas, sem autonomia nenhuma, nenhuma. Minha mãe era uma pessoa que não assinava um taláo de cheques, não fazia uma compra, era totalmente dependente do meu pai. E eu, desde muito pequena, tinha em mim a seguinte ideia: "quero trabalhar, quero ganhar dinheiro e não quero depender de homem nenhum." Mas era uma coisa que estava dentro de mim, não tinha nenhuma discussáo política em torno disso. Quando entrei na UFF, essa questão também não se colocava muito. A questão principal era a repressão, era a luta contra a ditadura, era o medo das perseguiçóes políticas. Naquele tempo, se discutia muito uma mudança de padráo, a prática do que se chamava de amor livre, uso da pílula anticoncepcional etc. E eu era um pouco bobinha. Não estava engajada, só tinha essa ideia de querer ser uma pessoa independente, trabalhar, ganhar o meu dinheiro, não tinha uma dimensão política maior da questão do feminismo.

O mestrado em História na UFF foi criado um pouco antes da minha formatura, em 1971. Logo no início, muitos professores eram brasilianistas, como Stanley Hilton, Richard Granham e também alguns ultraconservadores que vieram da UERJ, como Pedro Ribeiro; e umas figuras ilustres como a Lysia Bernardes. O mestrado da UFF foi um dos primeiros cursos de pós-graduação no país. No fundo, esse mestrado reuniu pessoas de diferentes orientaçóes. Havia um estímulo do MEC pra criar novos mestrados, e a UFF se apresentou como tal. Os professores eram oriundos de diferentes lugares: os brasilianistas, José Honório 
Rodrigues, Lysia Bernardes — que dava aula de Geografia — Arthur César Ferreira Reis, dentre outros. Neste momento a Ismênia Martins era uma recém-doutora, tinha acabado de defender o doutorado na Universidade de São Paulo e entrou para dar aula nesse mestrado. Ela era a pessoa com quem me senti mais familiarizada, até por ser mais jovem. Algumas pessoas escolheram o José Honório, o Pedro Ribeiro, que era professor de História da América. Nessa primeira turma também entrou o Victor Valla, um americano brasilianista que estava radicado no Brasil. Pensei que a pessoa mais interessante, com que sentia mais afinidade, era a Ismênia, que estava começando a carreira. A minha turma foi a primeira turma de Pós-graduação da Ismênia, nós fomos os primeiros orientandos de mestrado dela. Quando eu defendi a dissertação, a Ismênia fez uma festa na casa dela, um almoço maravilhoso, convidou a todos que foram assistir à defesa da dissertação. E fui trabalhar com o século XIX, que era a área que ela pesquisava.

Há um dado também interessante. Durante a minha dissertação de mestrado - para vocês verem como é que a barra era pesada naquela época -, eu conheci a Maria Yedda Linhares, que tinha voltado do exílio e estava fazendo traduções.

Entrevistadores: Foi ela quem falou que História oral era fofoca?

Marieta de Moraes Ferreira: Foi! Mas isso já foi mais tarde. Eu fiquei conhecendo a Maria Yedda através de uma amiga que fazia mestrado comigo, começamos a conversar e ela se interessou muito pelo meu trabalho. Levei meus capítulos e ela me deu várias sugestões, a gente discutiu bastante também. $\mathrm{Na}$ época da defesa, eu queria que ela participasse da banca e falei com a Ismênia, que me respondeu que ia tentar, achou ótimo, mas a direção da faculdade disse que não dava para convidar, e isso já foi em novembro de 1977, quando eu defendi o mestrado. Nessa altura, ela já estava até trabalhando, começando a dar aula no Programa de Pós-graduação em História da Agricultura, que era vinculado à Fundação Getulio Vargas, mas ela não pode participar da minha banca.

Quando me formei, fiz concurso para dar aula no Estado, dava aula numa escola em Copacabana, no Ensino Fundamental, e também me candidatei para trabalhar no colégio onde eu tinha estudado em Friburgo. Eles tinham uma Faculdade de Filosofia, então apresentei o meu currículo e eles me aceitaram pra dar aula na graduação em História. Logo depois também fiz concurso para a Casa de Rui Barbosa, para trabalhar como pesquisadora, e deixei o Estado do Rio como professora. Minha pesquisa era sobre os Comissários de Café, um pouco influenciada pela Ismênia e sua tese sobre o tráfico provincial na Província do Rio de Janeiro. Eu trabalhava na Faculdade de Filosofia em Friburgo e na Casa de Rui Barbosa, onde eles tinham um centro de História da Primeira República.

Em Friburgo foi muito interessante, porque as freiras me deram muita liberdade. Elas queriam renovar o curso, porque lá um professor dava aula de toda a História do Brasil e 
outro dava aula de todas as cadeiras de História Geral. Quando cheguei, comecei a conversar com as freiras que eu conhecia (algumas tinham sido minhas professoras no colégio, indicando que não podia ser assim, e elas também queriam mudar). Então levei meus colegas todos da UFF pra dar aula lá. Nós criamos um curso de História que ficou superbacana: Luiz Carlos Soares, Eduardo Silva, que hoje é pesquisador da Casa de Rui Barbosa, Sydney Solis, que depois foi professor da área de Sociologia na UERJ, João Raimundo, enfim, várias pessoas da UFF. Nós modernizamos o curso, especializamos as cadeiras.

Mas depois fiquei grávida, tive minha primeira filha, e ficou difícil ir para Friburgo toda semana. Neste momento apareceu uma oportunidade de trabalhar no CPDOC. Eles estavam procurando pessoas para trabalhar no Dicionário histórico-biográfico brasileiro, ${ }^{2}$ queriam alguém para trabalhar com História da Imprensa. Eu me apresentei. Não conhecia ninguém, fiz a entrevista e eles me aceitaram. Comecei a trabalhar com o "período pós-30", a "Era Vargas" e imprensa. E eu não sabia nada, porque a minha dissertação era sobre o século XIX. Na Casa de Rui Barbosa, eu tinha trabalhado com Primeira República. E, nos cursos de graduação de História, o período depois de 1930 não existia. História do Brasil terminava em 1930 e olhe lá.

Quando vim para o CPDOC, tive que me virar e comecei a estudar para fazer os verbetes; tive que fazer entrevistas... E, no CPDOC, a questão da História Contemporânea era muito importante, era a área principal. História Política também, História oral... Então, comecei a investir nisso, tanto que, quando eu decidi fazer o doutorado, já tinha mudado para História Política e período "pós-45", mas depois eu acabei não fazendo a minha tese sobre isso.

Entrevistadores: Como foi essa entrada na área de estudos de História oral?

Marieta de Moraes Ferreira: Quando cheguei, o CPDOC já tinha um programa de História oral que havia sido criado pela Aspásia Camargo e fazia entrevistas de história de vida com grandes personagens da política varguista, figuras ligadas ao Movimento Tenentista, à Revolução de 1930... A Aspásia coordenava essa área e tinha uma pequena equipe que trabalhava no programa de História oral. Eu não trabalhava no programa de História oral, eu trabalhava no Dicionário, mas tive de fazer muitas entrevistas com jornalistas, porque havia muito pouco material publicado, escrito, para fazer os verbetes relacionados aos jornais brasileiros do período que eu estava pesquisando. Entrevistei mais de trinta jornalistas. Uma boa parte dessas entrevistas nem consta no acervo do CPDOC, porque não eram entrevistas de história de vida, não tinham por objetivo integrar o acervo de História oral do CPDOC, e as fiz sem um preparo teórico-metodológico.

Até aí, minha aproximação com História oral era bastante circunscrita e sem uma refle-

${ }^{2}$ Dicionário histórico-biográfico brasileiro pós-1930. Rio de Janeiro: Ed. FGV, CPDOC, 1984. 
xão maior sobre seu estatuto, porque no CPDOC também não havia uma grande discussão teórica sobre História oral. Havia os projetos com as entrevistas, entrevistas estas muito bem elaboradas, mas a discussão sobre memória e distorções da memória surgiram quando Michael Pollak veio ao CPDOC e fez duas conferências com a temática da memória, esquecimento, silêncio e identidade, em meados dos anos 1980 .

A História oral tinha os desafios relacionados à "História vista de baixo", ${ }^{3}$ à História como uma militância política, à História pra dar voz aos esquecidos, aos marginalizados. E, com isso, problematizar uma entrevista de uma pessoa, que digamos, já fosse marginalizada, era muito polêmico. As entrevistas eram tomadas como expressão da verdade daquelas pessoas. A discussão de memória não frutificava muito.

Quando terminei o doutorado, fui coordenar o projeto de História oral do CPDOC. E, ao mesmo tempo, quando já estava terminando o doutorado, entrei para a UFRJ, em 1986. Comecei a dar aulas na UFRJ como professora visitante e, então, dei um curso na pós-graduação sobre fontes orais. Naquela época nem se falava nesse negócio de História oral, isso era lá um “palavrão”.

Nas Universidades, História do Tempo Presente ou similares eram coisas interditadas. As pessoas achavam que história recente era uma coisa de jornalista ou de cientista político, sociólogo... Historiador tinha que trabalhar com períodos mais recuados, para poder ter um distanciamento. Em 1988, fiz o concurso e, então, comecei de fato a trabalhar na pós-graduação e investir em dar cursos que envolviam as minhas experiências de pesquisas.

Entrevistadores: E como era a recepção dos alunos a estes cursos que eram tão novos?

Marieta de Moraes Ferreira: Os alunos gostavam muito! Em 1991, fui coordenadora do Programa de História oral. E, em 1992, 93, comecei a participar dessas discussóes que estavam acontecendo no Brasil. Em 1994, nós organizamos o primeiro seminário de História oral, que foi aqui no CPDOC, onde foi criada a Associação Brasileira de História oral. E, ao mesmo tempo, fui eleita a primeira presidente da Associação. Nessa altura dos acontecimentos, eu já tinha dado alguns cursos de História oral na UFRJ: "Memória e fontes orais"; "História do Tempo Presente"... Nessa época ninguém falava de História do Tempo Presente. Recentemente eu escrevi um artigo sobre a entrada da História oral no Brasil e resolvi fazer uma espécie de genealogia de quando começaram os trabalhos nesta área no Brasil. Por exemplo, o livro que se chama Reintroduzindo a História oral no Brasil, onde publiquei um artigo chamado "História oral e Tempo Presente", foi publicado em 1996.

Depois, entrei em outro projeto desenvolvido pela professora Alzira Abreu, sobre Histó-

\footnotetext{
${ }^{3}$ Perspectiva associada aos historiadores marxistas anglo-saxôes da segunda metade do século XX, como E.P. Thompson, Christopher Hill, Natalie Zemon Davis.

${ }^{4}$ In: MEIHY, José Carlos Sebe. Reintroduzindo a História oral no Brasil. São Paulo: Xama, 1996.
} 
ria fluminense, História do Rio de Janeiro. Coordenei este projeto com um grupo de pesquisadores que tinham trabalhado no Dicionário. A pesquisa era sobre a Primeira República e, assim, fui de fato me envolver, me voltar para a Primeira República, e fiz minha tese de doutorado sobre as Elites Políticas na Primeira República. Não fiz o projeto que eu queria, com o qual eu entrei no processo de seleção do doutorado na UFF, que era sobre partidos políticos de 1945 a 64.

$\mathrm{Na}$ época do Dicionário, além dos verbetes sobre imprensa, eu fiquei responsável pelos textos sobre os partidos políticos. Então, fiz verbetes sobre o Partido Trabalhista Brasileiro, João Goulart, o que acabou por me estimular muito nessa investigação. Também era um período em que estávamos vivendo a redemocratização. Em 1979 houve a anistia. Depois, no começo dos anos 1980, a mudança do sistema partidário, o fim do bipartidarismo, criação do pluripartidarismo, criação do Partido dos Trabalhadores, do Partido Democrático Trabalhista, do Partido Socialista, do Partido da Frente Liberal, do Partido Democrático Social, enfim, do Partido do Movimento Democrático Brasileiro que sucedeu o Movimento Democrático Brasileiro. Deste modo, os partidos políticos eram um tema muito importante na sociedade naquele momento. Eu queria muito estudar o PTB, que era o partido sobre o qual tinha feito o verbete. Apresentei um projeto que não era somente sobre o $\mathrm{PTB}$, era sobre o próprio sistema partidário de 1945 a 64. Mas, depois, como estava coordenando esse projeto focado na Primeira República, desisti do projeto sobre o sistema partidário. Acabei fazendo a minha tese sobre as elites políticas fluminenses, e até trabalhei com os partidos políticos na Primeira República.

Entrevistadores: Marieta, ainda a respeito da sua recepção pelos alunos, recentemente eu estava conversando com dois professores que me falaram sobre um conflito de geraçóes quando entraram para a UFF, entre antigos e novos professores. Quando a senhora entrou na UFRJ e começou a trabalhar com essas novas temáticas (História oral e História do Tempo Presente), havia também este conflito? Como foi a recepção dos professores?

Marieta de Moraes Ferreira: Não acho que houve propriamente um conflito de geraçôes, até porque, quando eu entrei na UFRJ, o curso estava muito esvaziado, havia passado por uma crise muito grande. Havia professores mais velhos, mesmo com a volta de Eulália Maria Lahmeyer Lobo, de Maria Yedda Linhares, de Bárbara Levy, ou mesmo Francisco Falcon, que ainda não tinha se aposentado. Mas muitos professores novos haviam entrado, então, não senti um conflito. No caso da História oral, eu até via um questionamento, mesmo de colegas da minha geração, como, por exemplo, o Afonso Carlos, que era da minha idade. Ele terminou a faculdade junto comigo, embora não fosse da UFF, tinha estudado na UFRJ, e entramos pra trabalhar como professores no Estado do Rio no mesmo ano. Ele era radicalmente contra a História oral, achava que era uma bobagem, uma besteira. Os mais velhos nem se fala, Maria 
Yedda, Eulália... Principalmente Maria Yedda. Ela me falava: "Minha filha, você é uma ótima historiadora, uma pesquisadora de fôlego" — porque para a minha dissertaçáo sobre Comissários de Café fiz uma pesquisa densa com manuscritos depositados no Arquivo Nacional, cerca de 400 ou 500 registros da junta comercial, uma pesquisa realmente difícil de ser executada. E ela dizia: "Você é uma pesquisadora muito boa e esse negócio de História oral, minha filha, isso é uma bobagem, não se envolve com isso que você tem um futuro como pesquisadora." $\mathrm{E}$ eu dizia: "Não, professora, mas isso não é bem assim, tudo depende de como você trabalha."

Ela gostava muito de mim e, depois que eu defendi a dissertação, ela queria muito publicar o meu trabalho, se empenhou para isso, mas acabou por não dar certo. Enfim, havia uma afinidade muito grande entre nós. Na própria UFRJ, demorou muito para haver um trabalho de História oral, pelo menos no curso de História. Apenas, muito mais tarde, a professora Maria Paula Nascimento Araújo começou a trabalhar com entrevistas. O lugar em que trabalhavam com História oral era mesmo o CPDOC. Nos Anais do primeiro encontro de História oral, que foi realizado aqui, há trabalhos do Museu da Imagem e do Som, da Fundação Oswaldo Cruz etc. O programa da UFF, que estava um pouco abalado, nesta época renasce, novos pesquisadores entram.

Mas eu não sentia, na UFRJ, uma resistência geracional contra mim, até pelo contrário. Por exemplo, Jose Luis Werneck, que era um professor mais velho, era uma pessoa muito receptiva. Ele quis que eu viesse para a UFRJ. Bárbara Levy foi a principal responsável por minha ida para a UFRJ. Então, não senti isso em relação a mim pessoalmente, mas, no que diz respeito à História do Tempo Presente e à História oral, havia uma resistência muito grande, de uma maneira geral, nas Universidades. Me lembro de participar em bancas de seleção para a pós-graduação na UFRJ, no Programa de Pós-graduação em História Social e aparecerem alunos com temas em História oral ou História do Tempo Presente e a banca perguntar: "Mas isso é um tema de História? Isso pode ser feito numa Pós-graduação em História?” E acabava que estes alunos iam para universidades mais novas, em outros estados que não os do Sudeste, como por exemplo o Mato Grosso, ou o Rio Grande do Sul, entre outros, onde havia programas de pós-graduação mais novos, e estes temas seriam melhor recebidos, tidos como importantes pra serem investigados naquela regiáo.

Este interesse pela história recente foi mais encabeçado pelos alunos do que pelos professores. A nova geração de alunos, nos anos de 1990, que prestou os concursos de mestrado e doutorado, é que foi trazendo em seus projetos temas muito recentes e trabalhos com História oral, com imagens, criando uma pressão. Neste mesmo período, especialmente depois da criação da Associação de História oral, em 1994, eu ministrei uma grande quantidade de palestras e cursos pelo Brasil; acho que viajei pelo Brasil inteiro. Me chamavam para ministrar cursos de curta duração, de extensão, palestras, conferências. E a Associação de História oral também teve um papel muito importante, criando uma rede de pessoas interessadas provenientes dos diferentes estados. Havia ainda os eventos que nós criávamos, como a reunião bianual da seção nacional, bem parecida com os moldes da ANPUH, as reunióes regionais...

E foi neste contexto que organizei o livro Usos e abusos da História oral, publicado em 
1996.5 O livro representava minha experiência como professora, tanto na UFRJ quanto nesses cursos que ministrava pelo Brasil. Minha principal intenção era quebrar a ideia de que História oral era só fazer entrevista. O CPDOC tinha até um manual produzido pela professora Verena Alberti sobre o assunto. Mas, no manual, também não havia uma grande discussão sobre o estatuto da História oral, sobre a questão da memória, entre outras. Então, resolvi organizar este livro. Chamei a professora Janaína Amado, que nessa época era docente da Universidade de Brasília e mais titulada, reconhecida que eu, exatamente para endossar o livro. Ela era uma pesquisadora mais experiente e que transitava em outras áreas. A ideia era mostrar que História oral era um campo de pesquisa da História, não algo à parte, à margem, como muitos historiadores da História militante defendiam.

Nós seguimos por este caminho, e, embora na França não se goste muito de História oral, lá se desenvolveu um tipo de abordagem de História oral muito interessante, no Institut d'Histoire du Temps Présent, com os trabalhos de François Bédarida, Michael Pollack, Henry Rousso etc. Nesta mesma época tomei contato com essas pessoas e nós os chamávamos para vir ao Brasil, participar dos congressos que organizávamos, como Mercedes Vilanova, o Alexander von Plato, Alessandro Portelli. Isso foi muito interessante e deu um dinamismo para a discussão e para a própria área, o que foi muito importante.

Entrevistadores: $\mathrm{E}$ como foi fazer um trabalho de pesquisa sobre um partido que estava no poder, como no caso do livro sobre o Partido dos Trabalhadores?

Marieta de Moraes Ferreira: Tenho duas experiências nessa área: uma as pessoas conhecem bem; a outra as pessoas conhecem muito pouco. Na verdade, eu acho que os dois livros circularam um pouco. $\mathrm{Na}$ época, eu era diretora do CPDOC. Eu me tornei diretora do CPDOC em 1999. Entre 1996 e 1997, eu fiz um pós-doutorado na França e, quando voltei, já estava mais ou menos discutido que eu seria diretora do CPDOC. Quando comecei em 1999 houve um desejo — veja só que coisa engraçada — do Partido da Social Democracia Brasileira de fazer um livro de depoimentos em torno da figura do Mário Covas.

Ele havia acabado de falecer de câncer. Vocês são muito novos, não lembram disso, mas a morte de Mário Covas foi um calvário, um entra no hospital, sai do hospital, volta para o governo, enfim. E a morte dele foi muito traumática, porque ele tinha tido um papel muito importante na redemocratização, na própria luta pela constituinte de 1988 ... Até por este papel-chave, queriam fazer um livro de depoimentos. Ele tinha morrido, entáo, a ideia era entrevistar pessoas que tinham vivido próximas a ele, vivenciado experiências com ele. Ficou um livro bacana, porque entrevistamos várias pessoas que eram do PSDB, como Fernando

\footnotetext{
${ }^{5}$ FERREIRA, Marieta de Moraes; AMADO, Janaína; (Org.). Usos e abusos da História oral. Rio de Janeiro: Ed. FGV, 1998.

${ }^{6}$ FERREIRA, Marieta de Moraes; FORTES, Alexandre (Org.). Muitos caminhos, uma estrela: memórias de militantes do PT. São Paulo: Ed. Fundação Perseu Abramo, 2008.
} 
Henrique Cardoso, mas também Delfim Neto, Pedro Simon - pessoas que não eram do PSDB, mas que haviam tido contato com ele ao longo de sua carreira política. ${ }^{7}$ Nós fizemos o livro, as entrevistas, mas ele acabou sendo publicado pela Fundação Mário Covas. Em vez de escolherem uma editora que desse circulação ao livro, fizeram uma produção interna e o livro desapareceu, ninguém conhece, lamentavelmente.

O projeto do livro sobre o Partido dos Trabalhadores se deu por conta desse livro, e também de muitos outros livros que o CPDOC tinha feito, sobre políticos proeminentes, jornalistas, elite empresarial, sobre a burocracia do Banco Central, Petrobras, Eletrobrás... Enfim, de fato nesse período o CPDOC abriu muito o leque em termos de História oral. Nos primeiros anos o foco era voltado para a elite política, figuras que participaram da "Era Vargas", e, depois, abriu-se o leque para outras áreas, começaram os trabalhos abordando períodos mais recentes; desenhou-se outro projeto sobre o Regime Militar e, então, Maria Celina D’Araújo e Celso Castro fizeram várias entrevistas com os militares nesse período ${ }^{8}$; também houve projetos sobre a Petrobras, BNDES, Banco Central... Saiu-se do universo da política e ampliou-se a pesquisa para o universo de História oral de instituiçóes da burocracia brasileira, o que gerou um acervo muito importante e muito grande. Eu fiz ainda um projeto sobre a Capes, que foi muito interessante. Entrevistamos todos os presidentes da Capes. ${ }^{9}$

Então, em função disso, o pessoal do PT, da Fundação Perseu Abramo, nos procurou para ver se queríamos fazer um projeto. Eu me interessei pessoalmente pela pesquisa e começamos a desenvolver o projeto. Só que, exatamente quando estávamos começando, surgiu a questáo do mensaláo. E isso gerou uma série de problemas, porque as pessoas estavam muito mexidas com aquilo, houve muitas dificuldades com o projeto. Tanto que ele era muito maior, o plano era desenvolvê-lo em três volumes, no livro publicado está escrito "volume um" e fizemos mais um montấo de entrevistas que estão arquivadas na Fundação Perseu Abramo e no CPDOC, com o Vladimir Palmeira, o próprio José Dirceu, e com várias outras figuras que comporiam o segundo volume.

Entrevistadores: Neste primeiro volume são 25 entrevistas. Qual foi o critério de seleçáo para estes entrevistados?

Marieta de Moraes Ferreira: O critério foi em grande parte dado pela Fundação Perseu Abramo, embora tivéssemos discutido. Eu não conhecia inclusive os meandros da fundação do PT, então o Alexandre Fortes trabalhou comigo nesse projeto. Ele era militante do PT. Tomamos a decisão de entrevistar pessoas que tinham participado do PT nos primeiros tem-

\footnotetext{
${ }^{7}$ FERREIRA, Marieta de Moraes; SARMENTO, Carlos Eduardo B. (Org.). Mário Covas: a ação conforme a pregação; uma revolução ética em São Paulo. São Paulo: Fundação Mário Covas, 2003.

${ }^{8}$ In: D’ARAUJO, Maria Celina; CASTRO, Celso (Org.). Ernesto Geisel. Rio de Janeiro: Ed. FGV, 1997.

${ }^{9}$ FERREIRA, Marieta de Moraes; MOREIRA, Regina L. (Org.). Capes, 50 anos: Depoimentos ao CPDOC, FGV. Rio de Janeiro: Ed. FGV, 2002.
} 
pos, da fundação do partido; também acordamos em contemplar uma diversidade regional e mulheres. Selecionamos as entrevistas de Benedita da Silva, Irma Passoni, Apolonio de Carvalho, Antonio Candido, Manoel da Conceição, dentre outros.

Entrevistadores: A velha guarda do PT.

Marieta de Moraes Ferreira: Da velha guarda, sim. Djalma Bom, Olívio Dutra, Paulo Rocha, Avelino Ganzer, Raul Pont, mas nós tínhamos a ideia de contemplar também diferentes regiôes. Olívio Dutra, do Rio Grande do Sul, Paulo Rocha, do Pará, e Avelino Ganzer, da Amazonia, Luiz Dulci, de Minas, Raul Pont, do Rio Grande do Sul, Hamilton Pereira, de Goiás, no sentido de conhecer como é que o partido se organizou, porque estas figuras tiveram um papel de liderança nessa organização local. Então esse foi o principal critério adotado. E havia ainda o segundo volume, que nunca saiu. Quando terminou o governo Lula, ficou aquela dúvida: vai fazer, não vai fazer, o que se vai fazer? E aí não foi pra frente.

Entrevistadores: Logo depois desse trabalho com o PT, a senhora fez uma série de entrevistas para o seu livro mais recente, $A$ História como ofício ${ }^{10}$ Ele está mesclado com diversas entrevistas dos anos 1990 e dos anos 2000. Parece que se trata do resultado de diversos artigos anteriormente publicados no decorrer desses anos, incluindo o capítulo publicado no livro organizado por Manuel Salgado Guimarães. ${ }^{11}$ Além disso, a senhora participou do I Encontro de História do Pensamento Geográfico.

Marieta de Moraes Ferreira: Em 1996, eu fui para a França, fazer um pós-doc com o Roger Chartier na EHESS, onde pesquisei sobre as missóes francesas que tinham vindo para o Rio de Janeiro para participar da criação da Universidade do Distrito Federal (UDF), em 1935, e da Faculdade Nacional de Filosofia da Universidade do Brasil, em 1939. Como resultado desse material sobre as missóes francesas, produzi o artigo sobre o geógrafo Pierre Deffontaines, que foi apresentado no I Encontro de História do Pensamento Geográfico, em 2000.

Entrevistadores: Quando a pesquisa foi planejada, o objetivo inicial era realmente estudar o Deffontaines ou o Henry Hauser?

Marieta de Moraes Ferreira: Esse ano passado na França, entre 1997 e 1998, foi o momento no qual levantei esses materiais. Eu queria estudar as missóes francesas que vieram para o Rio de Janeiro. A ideia de estudar esse tema veio da entrevista com a Maria Yedda Linhares. A entrevista não tinha ligação com o contexto da minha pesquisa, tanto que foi

\footnotetext{
${ }^{10}$ FERREIRA, Marieta de Moraes. A História como ofício: a constituição de um campo disciplinar. Rio de Janeiro: Ed. FGV, 2013.

${ }^{11}$ FERREIRA, Marieta de Moraes. Notas sobre a Institucionalização dos Cursos Universitários de História no Rio de Janeiro. In: GUIMARÃES, Manuel Luiz Salgado (Org.). Estudos sobre a Escrita da História. Rio de Janeiro: 7 Letras, 2006.
} 
uma produção realizada lá atrás, publicada na Estudos Históricos. ${ }^{12}$ Naquela época, havia uma ideia geral, na revista, de publicar entrevistas com cientistas sociais e historiadores estrangeiros. Foi nesse momento que começamos a defender a ideia de que se deveria entrevistar, também, cientistas sociais e historiadores brasileiros. Me candidatei para fazer a entrevista com a Maria Yedda e foi muito positivo, sobretudo porque durou bastante tempo. Ela era Secretária de Educação do governo Leonel Brizola, alocada em um prédio que ficava à Rua do Passeio, e a entrevista, portanto, tinha o intuito de dar destaque para uma trajetória interessante. Nessa entrevista, a Maria Yedda fala muito dos franceses, do Henry Hauser, do Pierre Deffontaines e do Francis Ruellan. Ela fala muito do Ruellan. Isso foi uma surpresa para mim, porque todo mundo só falava das missóes francesas da USP, de Fernand Braudel, Lévi-Strauss, que eram as figuras de grande destaque. Mas, nessa conversa com ela, eu pensei: "Esse é um tema interessante de pesquisa." E estava querendo ir para a França realizar uma pesquisa de pós-doutorado, mas não queria ir até lá fazer uma pesquisa como a maioria das pessoas faz, para estudar temas brasileiros. Pensava que, para estudar temas essencialmente brasileiros, podia-se estudar no Brasil. Queria ir até lá para desvendar um tema da historiografia francesa. O que tinha em mente era levantar todo esse material na França e foi o que fiz durante esse tempo, li a bibliografia dos cursos universitários, investi em conhecer as relaçóes desses pesquisadores.

Por acaso e sorte, acabei me aproximando da família de Deffontaines, conheci sua filha, fui até a casa onde ele morou, consultei seu diário. Além disso, conheci a filha de Henry Hauser; entrevistei um neto dele; entrevistei muitos ex-alunos da segunda missão; fui ao Musée d'Orsay para levantar os arquivos; e, principalmente, trabalhei muito pesquisando as publicações, as revistas francesas. Neste ponto, meu interesse era saber onde eles publicavam, qual era a rede que mantinham etc. Com isso, quando voltei tinha muita coisa levantada, então comecei a escrever. Nesse momento, escrevi o artigo sobre o Deffontaines e o artigo sobre as missóes francesas, que saiu naquele livro coordenado pelo Manuel Salgado. ${ }^{13}$ Eram as primeiras coisas publicadas sobre essa temática, mas acabei não investindo muito nessa pesquisa. Eu escrevi esses artigos e deixei isso parado.

Por essa época, eu assumi a direção do CPDOC e a presidência da Associação Internacional de História oral. Esse projeto ficou guardado na gaveta em face aos compromissos. Nós começamos a fazer os projetos de História oral e uma série de outros projetos avulsos. Também me envolvi muito com a organização e gestão administrativa. Era a época em que estávamos criando a Escola do CPDOC, a Pós-graduação em História, Política e Bens Culturais, entre

${ }^{12}$ FERREIRA, Marieta de Moraes. Uma entrevista com Maria Yedda Linhares. (Entrevista). Revista Estudos Históricos, Rio de Janeiro, v. 5, n. 10, p. 216-236, 1992. Disponível em: <http://bibliotecadigital.fgv.br/ojs/ index.php/reh/article/view/1946/1085>.

${ }^{13}$ FERREIRA, Marieta de Moraes. Diario Personal, autobiografía y fuentes de Pierre Deffontaines. Historia, Antropología y Fuentes Orales, Barcelona, n. 24, p. 95-106, 2000; FERREIRA, Marieta de Moraes. Os professores franceses e o ensino da História no Rio de Janeiro nos anos 30. In: MAIO, Marcos Chor; VILLAS BÔAS, Glaucia (Org.). Ideais de Modernidade e Sociologia no Brasil - Ensaios sobre Luiz de Aguir Costa Pinto. Porto Alegre: Ed. UFRS, 1999. 
outros. Era um trabalho que demandava muito. Sem contar que eu continuava dando aula na Universidade Federal do Rio de Janeiro, com orientaçôes e carga em sala de aula, pois é uma coisa de que gosto muito. Foi um período muito cheio, que se prolongou até 2005.

Quando saí da direçáo do CPDOC, era o momento de retomar os projetos sobre o curso de História da Universidade do Distrito Federal. Eu já havia pesquisado sobre a missão francesa. Entáo, estava no momento de olhar como se desenhava esse curso, ou seja, quem dava aulas, como se estruturava, quem eram seus integrantes e suas redes, como se desenrolou o primeiro projeto da Universidade do Distrito Federal e, depois, o projeto na Faculdade Nacional de Filosofia. Nesse contexto, eu escrevi o trabalho para o livro de Manuel Salgado Guimaráes. ${ }^{14}$ Eu era e sou bolsista de produtividade do CNPq, e você tem de produzir anualmente artigos para justificar seus projetos, então estava debruçada sobre essa temática e seus desdobramentos.

Em 2013, eu quis reunir esses trabalhos, que estavam muito dispersos ou haviam se perdido completamente. Alguns deles estavam desaparecidos e o conjunto estava totalmente fragmentado. Foi o período coincidente com o investimento em novas entrevistas, que havia começado em 2008. Neste primeiro ano, nós realizamos um acordo de cooperação internacional entre a Capes, a École Normale Supérieure - Paris III, o CPDOC e a UFRGS. Fui para a França e pude retomar uma série de pesquisas que eu ainda queria fazer, temas que careciam de investigação. Quando voltei, pouco tempo depois, ingressei no pós-doutorado na USP. Só entấo foi possível completar todas aquelas entrevistas, fazer os novos textos e, em alguns casos, retrabalhar material anteriormente publicado. Foi a janela para juntar tudo aquilo no livro História como ofício e tornar possível que as pessoas pudessem observar, de forma mais adequada e organizada, aquele conjunto.

Entrevistadores: Em toda esta conversa, pautada pela experiência como professora, pesquisadora e gestora - do CPDOC e da Editora da FGV — reside algo de muito interessante, porque essa é uma trajetória um pouco incomum à maioria dos historiadores. Como é essa conciliação entre uma carreira administrativa, que teoricamente não está direcionada a alguém com formação em humanidades, e a carreira de professora-pesquisadora na universidade pública brasileira?

Marieta de Moraes Ferreira: É, sem dúvida, um desafio grande juntar essas coisas. Em alguns momentos você acaba por priorizar mais umas coisas em detrimento de outras. Por exemplo, como nesse período em que fui diretora do CPDOC e presidente da Associação Brasileira de História oral o investimento em pesquisa de fôlego ficou prejudicado. Não se deixa de produzir, de fazer livros, como o do Mário Covas, de apresentar papers em congres-

\footnotetext{
${ }^{14}$ FERREIRA, Marieta de Moraes. Notas sobre a Institucionalização dos Cursos Universitários de História no Rio de Janeiro, op. cit.
} 
sos nacionais e internacionais, principalmente em História oral. Mas um pesquisador que está envolvido em diversas atividades de gestáo dificilmente dará conta de se aprofundar sobre um material mais extenso, de fazer uma série de leituras teóricas etc. Uma coisa que sempre me ajudou, pensando agora, foi a ideia de continuar dando aulas. Você, quando dá aulas e orienta, também está aprendendo. Não se pode deixar de ler e reler muitas coisas, de se atualizar. Eu sempre trabalhei muito, acredito que tenha uma capacidade de trabalho bastante considerável. Entâo, o final de semana vira dia útil, a organizaçáo precisa ser nesse sentido. Mas não é uma reclamação, isso me ajuda. Esse projeto do PROFHISTORIA foi muito levado para a frente por conta dessa capacidade adquirida dentro de uma experiência de gestão. Agora, eu acho que a minha maior experiência de gestão é no campo da política institucional. Ser capaz de reunir pessoas, trabalhar junto, aparar arestas e tensóes que fatalmente surgem nos projetos, talvez seja a maior qualidade que consigo enxergar.

Certamente, acredito que, se o empreendimento de gestão de grandes projetos não tivesse passado pelo meu caminho, eu teria uma obra melhor, maior, mais consistente. Ter publicado mais, ter investido mais ou ter trabalhos que tivessem uma densidade teórica maior, seria possível. Mas são escolhas, não dá para fazer tudo superbem. Então, de qualquer forma, eu fiz alguma coisa. O caso é que me dediquei à gestão sem nunca abrir mão da pesquisa, porque muitos professores enveredam pela carreira administrativa e abandonam a sala de aula, a orientação, a pesquisa. Não seguiria por essa senda, porque gosto e acho importante a aula na graduação, isso nunca foi um problema. A gestáo, para mim, acabou passando por isso, ser capaz de reunir pessoas ao redor de um projeto. O PROFHISTORIA foi muito isso: a reunião de uma equipe de colegas excelentes de diferentes instituiçóes.

Entrevistadores: A ideia do PROFHISTORIA é realmente incrível, porque ele reúne pessoas de diferentes universidades em um projeto único, que é muito bem articulado e com forte entrada entre os professores que estavam fora do circuito acadêmico. Nós conhecemos muitos professores de escolas particulares e públicas que estão voltando para a universidade, em mestrados ligados ao ensino, à realidade da sala de aula. A senhora poderia falar um pouco mais dele?

Marieta de Moraes Ferreira: Esse momento é realmente muito importante, para mim em particular, e para o PROFHISTORIA em geral. No Encontro da ANPUH (Associação Nacional de História), em 2017, nós promovemos uma eleição para a direção do projeto e foi escolhida a nova equipe. Eu fiquei no cargo até $1^{\circ}$ de outubro, para fazer a transição. E, também este ano (no fim de 2017), eu vou me aposentar das atividades na UFRJ. É um momento de balanço, e o PROFHISTORIA foi muito importante na minha vida. Não só na minha, mas provavelmente na de todos os colegas que participam, pois é um espaço onde se sente de forma direta o resultado do trabalho, o impacto na vida das pessoas. Alguns são professores 
que estão em regiôes distantes do Brasil e viajam muitas horas toda semana para assistir a uma aula do mestrado profissional. Ao final, o resultado expresso em uma dissertação, que será aplicada em sala de aula, é algo fantástico. Nós fomos muito bem no projeto, que foi conduzido até aqui com pouquíssimo dinheiro. Nunca ocorreu uma discussão ou uma distensão, o percurso foi conduzido, ainda que pudesse haver divergências, com muita maturidade. Sempre os pensamentos foram levados de maneira a produzir os objetivos esperados. Todos foram capazes de ceder, porque, em alguns casos, nós trabalhamos com pessoas rígidas; algumas vezes, os pontos de vista não convergiam, como é natural, mas atendiam bem aos interlocutores. Pode-se, assim, verificar a validade de opinióes distintas, sem se abrir mão das coisas que eram fundamentais para seguir dentro do planejado. No geral, o produto foi sempre de aprendizado, tanto com os colegas de outras universidades quanto com os professores da educaçáo básica.

Enrevistadores: Como foram as costuras para que o PROFHISTÓRIA ganhasse vida?

Marieta de Moraes Ferreira: Ao contrário do que se imagina, não foi tão difícil, a princípio. Na verdade, tudo começou porque a Capes se interessou, já há algum tempo, em criar mestrados profissionais em ensino. Foi criado o PROFMAT, o PROFLETRAS etc. Aí, o professor Carlos Fico, que, na época, já era o representante da área de História junto à Capes, me perguntou um dia: "Marieta, a Capes está lançando mestrados profissionais em diferentes áreas, eu acho que nós deveríamos fazer um projeto para levar adiante um mestrado profissional em ensino de História. Você não gostaria de ficar à frente desse projeto?” Porque, naquela época, já existia o mestrado profissional do CPDOC, que foi criado no momento em que eu era diretora e coordenei um grupo de pessoas para que se encaminhasse o projeto à Capes. Ele disse: "Você já tem certa experiência e acredita nisso, acho que seria interessante conversar com as pessoas etc." Eu respondi prontamente que "Sim!".

Comecei então a conversar com os colegas. Há algum tempo defendi, em uma reunião do Fórum de Coordenadores, que a área de Ensino de História deveria ser objeto de uma atenção maior nos programas de pós-graduaçáo. Nesta ocasiáo, eu e alguns professores, como a Regina Bustamante, a Keila Grinberg e outras pessoas de outras instituiçôes, tínhamos feito uma carta dirigida à Capes, sugerindo que o ensino de História merecia mais cuidado. A produção de material didático era um dos pontos mais importantes dessa valorização, dentre vários outros. Na época, o Manoel Salgado era o coordenador do Fórum de Coordenadores de pós-graduação, mas de qualquer modo isso ficou suspenso. O que interessa é que já existia uma aproximaçáo com essa pauta, provavelmente por isso o Carlos Fico veio me consultar. Já existiam contatos entre mim, a Keila e a Regina Bustamante, conversas anteriores sobre isso. Foi necessário buscar outras pessoas da UFRJ, da Faculdade de Educação, como a professora Ana Monteiro e a professora Carmen Gabriel, por exemplo. Nós começamos a trocar ideias, a realizar reunióes regulares, foram se integrando novas pessoas, da Universidade do Estado do Rio de Janeiro, da Universidade Federal Fluminense, da Universidade Federal do 
Estado do Rio de Janeiro, da Pontifícia Universidade Católica do Rio de Janeiro, da Universidade Federal Rural do Rio de Janeiro. As conversas foram se desenrolando sobre o que se faria, como se faria, o que se evitaria. O grupo foi se modificando e se consolidando.

Em agosto de 2012, as discussões já tinham amadurecido e começamos a montar o projeto, definir as linhas etc. Foi um trabalho a várias mãos e algumas pessoas tiveram um trabalho muito importante. Foi um trabalho imenso, porque precisávamos montar ementa para todas as disciplinas. Nós enviávamos e-mail com chamada para os colegas, "Precisa-se de ementa para História da África”; esperávamos as respostas chegarem, arrumávamos a ementa, selecionávamos a bibliografia. $\mathrm{O}$ que se esperava era que o resultado se configurasse em um projeto para o Rio de Janeiro, um PROFHISTORIA fluminense, com as seis universidades daqui. Quando se aproximou o final do ano, se bem me lembro, em dezembro, nós fomos para a Capes. Pedimos para o Carlos Fico agendar uma reunião com o diretor de avaliação, que nessa época era o Lívio Amaral, para que ele conversasse e explicasse como seria o funcionamento. As dúvidas eram muitas: de quais instituiçóes eram os alunos? Como seriam as orientaçóes? Quem emitia o diploma? Como se constituía o vínculo? Colocamos tudo na mesa e ele disse: "Caso a ideia seja fazer uma rede, não dá para ser local, deve ser uma rede nacional. E, vocês precisam apresentar isso tudo, pronto, até o final de março do próximo ano."

Nós não juntamos o Brasil inteiro, era impossível em três meses. Convidamos três programas do Rio Grande do Sul, dois programas de Santa Catarina, um programa do Tocantins e um programa do Rio Grande do Norte. Na verdade, foi o que se conseguiu. Cada um trabalhou com os contatos mais imediatos de que dispunha. Algumas pessoas do Rio Grande do Sul já sabiam do projeto - professores da Universidade Federal de Santa Maria e da UFRGS (Universidade Federal do Rio Grande do Sul), como, por exemplo, a Claudia Wasserman, que era representante também junto à Capes e foi quem estimulou os pesquisadores da UFRGS a entrar no projeto. Além dessas entrou, também, a FURG (Universidade Federal do Rio Grande). A professora Helenice Rocha fez contato com o pessoal de Santa Catarina; eu tinha contato com o Tocantins e com o Rio Grande do Norte. Enfim, montamos nessas condiçóes. Pode-se ver que era uma coisa muito limitada. Tentamos acionar Minas Gerais, mas não foi em tempo; bem como outras instituiçốes de outros estados.

Entrevistadores: A entrada de outras universidades alterou significativamente a estrutura do projeto inicial do PROFHISTORIA? Quando entravam outras universidades entravam outras demandas?

Marieta de Moraes Ferreira: $\mathrm{O}$ tempo era curto, entâo, quando convidávamos alguma universidade, o que se podia fazer era apresentar o projeto com a ressalva de que náo daria para mudar. Tratava-se de um aceite ou náo da proposta que já estava pronta. Não havia tempo, nós saímos de Brasília no dia 15 de dezembro, com o ano já terminado. A ideia, que se carregou durante a viagem de volta, era de uma impossibilidade. No começo de janeiro, nós reunimos a 
equipe do Rio de Janeiro e perguntamos se todos estavam dispostos a seguir adiante. A reuniáo foi numa sala pequena do Instituto de Filosofia e Ciências Sociais, ao lado da sala que atualmente abriga o PROFHISTORIA. Quando nós apresentamos a questão, foi unânime: todos acharam que deveríamos seguir com o projeto. A partir daí, a maior dificuldade foi tramitar aquilo dentro da burocracia da UFRJ em um tempo que atendesse ao estabelecido pela Capes.

Ninguém tinha muita noção das várias instâncias pelas quais passaria todo processo. Começamos com uma reunião extraordinária, dentro do Instituto de História, para aprovar. Depois, levamos correndo para a Ana Maria Monteiro apresentar ao Centro de Filosofia e Ciências Humanas $(\mathrm{CFCH})$, mas a reunião que estava marcada acabou não acontecendo por um problema de última hora. Quando nós finalmente conseguimos a aprovação do $\mathrm{CFCH}$, o prazo para apresentar à Pró-Reitoria de Pós-graduação e Pesquisa já havia acabado. A resolução interna era de que não se aceitaria mais pedidos de mestrado profissional. Marcamos uma reunião de imediato com a Pró-reitora, mas não se sabia no que iria resultar. Ela viu o projeto e se deu conta de que era uma iniciativa muito importante para a UFRJ, mas que deveria ser chancelada pela Capes. Então, chegou à Pró-reitoria uma carta solicitando que se reconsiderasse o projeto no Conselho Universitário. Eram duas votaçóes distintas, a primeira consistia em reconsideração para avaliação ou não, e a segunda consistia na avaliação do projeto em si. Finalmente aprovado, o reitor assinou e estava pronto. Em agosto de 2013 a primeira turma estava funcionando.

Entrevistadores: Quais foram as mudanças pelas quais o programa passou?

Marieta de Moraes Ferreira: No começo, eram 12 universidades e cerca de 145 alunos. Aí, sim, começou a novela, por conta do financiamento, questóes de repasse entre a Capes e a UFRJ. O primeiro problema aconteceu antes mesmo do início das aulas, pois não havia recursos para fazer o processo seletivo. A solução foi encontrada junto ao Núcleo de Seleção Acadêmica da UERJ, que realiza até hoje o vestibular da instituição. A cobrança era realizada e a taxa de inscrição dos candidatos financiava o processo. A passagem dos funcionários era a maior despesa, porque eles tinham de ir até os núcleos do projeto para supervisionar a aplicação da prova. Um ano e meio após isso, com a situação já estabilizada, outras IES começaram a se interessar em participar espontaneamente. Foi quando abrimos um edital de seleção para novas universidades. Hoje são 27 núcleos, com cerca de 900 alunos em fase de qualificação e processo seletivo para 2019 aberto. É, sem dúvidas, um projeto qualitativamente e quantitativamente muito importante, e tenho a certeza de que darão continuidade com toda competência.

Entrevistadores: Mudando de assunto, a senhora sempre esteve à frente de movimentos de renovação da historiografia. Recentemente, fez uma visita à Europa para um congresso sobre repositórios digitais. Além disso, realiza um importante trabalho na Editora da FGV e no CPDOC, que tem tradição de História oral e História do Tempo Presente, de acervos 
abertos e acesso pela internet, de digitalizaçôes. Como se colocam estas questóes para o historiador e na historiografia brasileira hoje?

Marieta de Moraes Ferreira: Eu fui para Veneza, para o Congresso Internacional, organizado por uma entidade chamada COAR (Confederation of Open Access Repository), que discute plataformas digitais de acesso aberto. Estavam presentes diversas universidades e instituiçóes, como o MIT (Massachusetts Institute of Technology), que foi quem criou o DSpace. ${ }^{15}$

No que se refere à historiografia brasileira, esse é um ponto que ainda não é amplamente discutido pela comunidade de pesquisadores. Ela sofre as consequências disso, porque os desafios que estão colocados são muito grandes. Aqui na Editora da FGV, nós passamos por um processo de inovação quando, há três anos, resolvemos contratar uma empresa para estudar a possibilidade de implementar uma plataforma de livros digitais, ebooks. Até então, nenhuma editora universitária possuía esse serviço. Nós começamos a vender e disponibilizar os ebooks e os epubs - que são livros digitais melhor preparados e mais sofisticados. Foi um processo extremamente difícil do ponto de vista operacional, de como fazer funcionar, de como transformar os livros físicos em ebooks, e, principalmente, de como vender esses livros. Hoje, temos uma plataforma e quase todos os livros também estáo em formato digital, livros estes que são vendidos no site da Editora e em outras plataformas, como Google e Apple. Mesmo assim, é um mercado que, contra todas as apostas, não tem crescido. Por exemplo, há pouco tempo, conversamos com uma das editoras da Cambridge University Press, que apresenta os resultados mais surpreendentes em vendas em mídias digitais. Dentro de todas as vendas, os livros digitais não representaram nem $20 \%$ do total. Mesmo assim, é bastante, se comparado com o que vendemos aqui no Brasil. Portanto, esse é um lado, a plataforma de acesso restrito. Por outro lado, existe o acesso aberto. Aqui na Fundação Getulio Vargas, o Editor-chefe também é responsável pelas bibliotecas, onde temos o Repositório Digital FGV ${ }^{16}$ É lá que está todo material de acesso aberto, como os livros, as revistas - indexadas na Plataforma OJS (Open Journal Systems) ${ }^{17}$ — e outros textos variados, artigos, papers, documentos e toda produção das várias Escolas da Fundação Getulio Vargas.

A tecnologia é um desafio constante, porque a todo o momento é necessário pensar como se trabalha, como se melhora o acesso, a qualidade da informação, a velocidade dos dados, a divulgaçáo, a visibilidade, enfim, uma série de procedimentos. Pensando nisso, nós decidimos participar desse congresso em Veneza e associar o Sistema de Biblioteca FGV a essa entidade internacional, a COAR. Ela é uma rede internacional de bibliotecas e de escolas, sediada na

${ }_{15}$ Plataforma do Instituto de Tecnologia da Universidade de Massachusetts criada em 2004, com acesso aberto, que contém artigos, relatórios, teses e dissertaçóes de todos os departamentos do MIT datando desde meados dos anos 1800. Disponível em: <https://dspace.mit.edu/>.

${ }^{16}$ O Repositório é um dos canais de Pesquisa da Biblioteca Digital FGV, no qual é possível acessar de forma aberta e gratuita imagens, artigos, teses, dissertaçóes, vídeos, relatórios de pesquisa e bancos de dados. Disponível em: <http://bibliotecadigital.fgv.br/dspace/>.

${ }^{17}$ Open Journal Systems $(O J S)$ é um software de gerenciamento e publicação de revistas eletrônicas disseminado no Brasil pelo Instituto Brasileiro de Informação em Ciência e Tecnologia (IBICT) do Ministério da Ciência e Tecnologia. 
Alemanha. Então, nós estamos pouco a pouco tomando par dessa discussão, aprendendo.

Entrevistadores: $\mathrm{O}$ interessante, nesse caso, é estar nas duas pontas do processo, como historiadora e como editora. De que forma se colocam as diferentes necessidades destas duas ocupaçóes?

Marieta de Moraes Ferreira: Existe uma questão que precisa ser equacionada, cuja resposta eu não tenho. De um lado, a produção de um livro implica um custo. Vou dar um exemplo de um dos nossos últimos exemplares: A última catástrofe, do Henry Rousso. ${ }^{18}$ Eu fui à Feira do Livro de Frankfurt, comprei os direitos da editora francesa, gastamos uma cifra x para a tradução, outra para a revisão técnica, a diagramação, o copidesque e a impressão. São muitos trabalhos envolvidos que, ao final, têm um custo alto. Quando fui dar aula, no começo desse ano, recomendei a leitura. No dia seguinte, uma aluna havia escaneado e ofereceu distribuir para a turma. É uma situação comum na universidade, mas, de qualquer forma, como editora, fiquei preocupada porque acompanhei toda a produção do livro. Entáo, reside aí um desafio muito grande, uma despesa, alguém precisa pagar isto. Em uma editora privada, o objetivo principal é o lucro. No caso da Fundação Getulio Vargas, que é um misto de empresa e fundação privada de direito público, não existe a intenção de que um livro dê lucro. A Editora da FGV não existe para dar lucro, não é esse seu objetivo. Mas ela precisa se pagar, precisa ter um orçamento que pague os custos. Náo se recebe dinheiro do governo para as publicaçóes, entáo, há de se pagar as contas do que se imprime. O que temos é uma editora, que utiliza os serviços de uma plataforma da Adobe, que emprega um mecanismo chamado DRM (Digital Rights Management), que é uma espécie de trava para não permitir o acesso aberto, a cópia não autorizada.

Por outro lado, temos o Repositório Digital da FGV, contando com mais de 20 mil títulos em acesso aberto. Na verdade, o que se procura fazer, mesmo sem ter mostras seguras de que é a melhor saída, é pagar os custos. Um livro que, por exemplo, foi pago por uma fundação ou agência de fomento federal ou estadual está pago. Você pode colocá-lo em acesso aberto. As revistas hoje se encontram todas em acesso aberto, é uma diretriz da Capes e do Scielo. Você pode consultar muita coisa. Porém, os livros que estão em lançamento, com os custos ainda não cobertos, não podem ser colocados em acesso aberto.

Os livros com a impressão já realizada caem em um terceiro nicho de possibilidades. A edição que teve impressão de mil exemplares e cuja reimpressão não compensa financeiramente a editora será colocada como livro digital; ou à venda por um custo menor ou em acesso aberto. É um mercado que está em transição. Não se sabe para que lado e em que velocidade o livro digital irá avançar. O grande problema, que está no centro do debate sobre acesso aberto, são as multinacionais que montam bases de dados de livros, revistas, artigos, documentos, e vendem por preços absurdos. O Portal de Periódicos da Capes, por exemplo,

\footnotetext{
${ }^{18}$ ROUSSO, Henry. A última catástrofe: a história, o presente, o contemporâneo. Rio de Janeiro: Ed. FGV, 2016.
} 
paga verdadeiras fortunas para grandes grupos editoriais europeus.

Entrevistadores: Para finalizar, nós propomos uma reflexão metacrítica. A senhora informou que irá se aposentar. Então, existe um espaço para que a construção da sua memória comece a ser realizada de forma mais incisiva. Como é pensar, para uma historiadora da história oral, que fez muitas entrevistas com seus pares, a construção da sua própria memória?

Marieta de Moraes Ferreira: Acredito que tudo que estudei sobre história e memória se aplica a mim da mesma forma que se aplica aos outros. Evidentemente, esquecimentos são involuntários, mas a memória também é seletiva. Muitas coisas que eu disse aqui, para vocês, podem ser fruto de enganos. Eu digo que era na gestão do Manoel Salgado, mas talvez não fosse. Por isso eu acho que as entrevistas de História oral têm, pelo menos, uma dupla abordagem. Uma delas envolve as questóes que se colocam na interação entre a memória e o esquecimento. A recuperação que estou fazendo aqui está baseada em vivências pessoais, em experiências particulares etc. Caso você faça as mesmas perguntas para uma outra pessoa que participou do PROFHISTORIA, ela contará a mesma história de uma maneira diferente, um outro relato. $\mathrm{Ou}$, caso você interrogue um pesquisador do CPDOC e peça para ele falar do projeto de História oral, tenho certeza de que será outro relato. Até porque as pessoas atribuem a si próprias e aos outros papéis diferentes. Na História oral acontece muito isto: aquele narrador que acha que é o centro de tudo e que fez tudo sozinho; ou aquele outro que acha que não fez nada, que sua trajetória não tem grande relevância. Então, certamente, você poderá ouvir outras histórias de que não me lembrei ou que, porventura, tenham um viés de preferências por assuntos, pessoas, temas, abordagens. Acontece isso.

O pesquisador pode e deve se perguntar: "Então tudo que se fala é passível de ser questionado? Tudo que você está falando pode ser questionado?” Não. Muitas coisas que são ditas são informações verificáveis. $\mathrm{O}$ entrevistador ou o leitor pode recolher as informações da entrevista e entrecruzar com dados. Nesta entrevista, por exemplo, você pode entrar no site da Capes, solicitar vistas do processo do PROFHISTORIA à UFRJ, confrontar diversos documentos escritos, ouvir outras pessoas etc. A construção do conhecimento histórico se dá fundamentalmente sobre a articulação de diferentes fontes e diferentes versóes. A memória que estou colocando aqui, desses projetos nos quais me envolvi, é muito mais clara em relação às coisas recentes do que em relação aos acontecimentos mais antigos. Uma entrevista comigo sobre o período em que fui aluna na Universidade Federal Fluminense, sobre o curso de graduação, seria mais difícil. Náo me lembraria de todos os professores, das disciplinas, dos colegas... No começo desse relato, eu passei muito rapidamente pelo curso de História da UFF. Não falei dos professores que tive lá, mas vale citar pelo menos dois: a professora Vânia Fróes, de História Antiga, com quem aprendi muita coisa, e o Almir Chaiban El Kareh, que dava aula de Introdução à Economia Política. Depois outros professores que entraram 
mais tarde, como o Francisco Falcon e o Ilmar de Mattos, mas eles já entraram quando nós estávamos do meio para o final do curso. Portanto, não tiveram o mesmo impacto como os nossos professores dos primeiros anos. Enfim, existe um silenciamento, uma distorção de algumas partes que são incontornáveis.

Entrevistadores: Em outras entrevistas, percebemos que existe uma preocupação do entrevistado no sentido de construir uma versão de sua memória pessoal. Quais são suas preocupaçôes em relação a essa memória como professora, pesquisadora e gestora? Isso já passou pelos seus pensamentos?

Marieta de Moraes Ferreira: É claro que existe uma preocupação pessoal de divulgar o trabalho que fiz ao longo da minha vida. Não posso dizer que essa preocupação não me atinge. Dependendo do momento, o que fazemos é enfatizar mais um aspecto do que o outro. Neste momento, por exemplo, o que ganha destaque é o PROFHISTORIA, porque terminei há pouco tempo o mandato, é um projeto que tem uma visibilidade e uma importância muito grande, entre outras coisas. $\mathrm{O}$ momento acaba condicionando a maneira como se recupera o passado. Isso nós lemos nos teóricos, mas não deixa de se aplicar à nossa própria vida. Essa análise do passado fica pautada pelo presente, é nele que o passado ganha significado. 